\title{
Generation of an Infectious Clone of a New Korean Isolate of Apple chlorotic leaf spot virus Driven by Dual 35S and $\mathrm{T} 7$ Promoters in a Versatile Binary Vector
}

\author{
Ik-Hyun Kim ${ }^{1 \dagger}$, Jae-Yeong Han ${ }^{1 \dagger}$, In-Sook Cho ${ }^{2 \dagger}$, HyeKyoung $\mathrm{Ju}^{1}$, Jae Sun $\mathrm{Moon}^{3,4}$, Eun-Young Seo ${ }^{1}$, \\ Hong Gi Kim ${ }^{1}$, John Hammond ${ }^{5 *}$, and Hyoun-Sub Lim ${ }^{1 *}$ \\ ${ }^{I}$ Department of Applied Biology, College of Agriculture and Life Sciences, Chungnam National University, Daejeon \\ 34134, Korea \\ ${ }^{2}$ Horticultural and Herbal Crop Environment Division, National Institute of Horticultural and Herbal Science, Rural \\ Development Administration, Wanju 55365, Korea \\ ${ }^{3}$ Molecular Biofarming Research Center, Korea Research Institute of Bioscience \& Biotechnology, Daejeon 34141, \\ Korea \\ ${ }^{4}$ Biosystems and Bioengineering Program, University of Science and Technology, Daejeon 34113, Korea \\ ${ }^{5}$ United States Department of Agriculture - Agricultural Research Service, United States National Arboretum, Floral \\ and Nursery Plants Research Unit, Beltsville, MD 20705, USA
}

(Received on May 31, 2017; Revised on August 1, 2017; Accepted on August 8, 2017)

The full-length sequence of a new isolate of Apple chlorotic leaf spot virus (ACLSV) from Korea was divergent, but most closely related to the Japanese isolate A4, at $84 \%$ nucleotide identity. The full-length cDNA of the Korean isolate of ACLSV was cloned into a binary vector downstream of the bacteriophage T7 RNA promoter and the Cauliflower mosaic virus $35 \mathrm{~S}$ promoter. Chenopodium quinoa was successfully infected using in vitro transcripts synthesized using the $\mathrm{T} 7$ promoter, detected at $\mathbf{2 0}$ days post inoculation (dpi), but did not produce obvious symptoms. Nicotiana occidentalis and $C$. quinoa were inoculated through agroinfiltration. At 32 dpi the infection rate was evaluated; no $C$. quinoa plants were infected by agroinfiltration, but infection of

\footnotetext{
These authors contributed equally to this work as first authors.

*Corresponding authors.

H-S Lim

Phone) +82-42-821-5766, FAX) +82-42-823-8679

E mail)hyounlim@cnu.ac.kr

J Hammond

Phone) +1-301-504-5313, FAX) +1-301-504-5096

E-mail ) John.Hammond@ars.usda.gov

(c) This is an Open Access article distributed under the terms of the Creative Commons Attribution Non-Commercial License (http:// creativecommons.org/licenses/by-nc/4.0) which permits unrestricted noncommercial use, distribution, and reproduction in any medium, provided the original work is properly cited.
}

Articles can be freely viewed online at www.ppjonline.org.
N. occidentalis was obtained.

Keywords : agroinfiltration, Apple chlorotic leaf spot virus, full-length infectious cDNA clone, in vitro transcription, $\mathrm{T} 7$ promoter

Handling Associate Editor : Lee, Jungkwan

Apple (Malus domestica, family Rosaceae), is an important fruit cultivated worldwide. Ten varieties are commonly cultivated commercially in Korea, mainly in Gyeongsang and Chungcheong Provinces, where 92\% of Korean apples are produced. High-throughput sequencing methods have recently identified new viruses including Apple stem grooving virus (ASGV), Apple chlorotic leaf spot virus (ACLSV), Apple stem pitting virus (ASPV), Apple green crinkle-associated virus (AGCaV) and Apricot latent virus (Cho et al., 2016), and Apple mosaic virus (ApMV) in Korea (Lee et al., 2002). ACLSV is one of the most economically important viruses because infections can induce yield losses of 30-40\% (Cembali et al., 2003; Nemchinov et al., 1995; Wu et al., 1998). Most apple cultivars do not produce obvious symptoms when infected with ACLSV, but we previously identified one sensitive apple cultivar that occasionally showed distinctive symptoms when infected with ACLSV (Han et al., 2015). 
Apple trees are propagated through grafting, and regularly pruned; therefore, latent ACLSV infections can be transmitted from infected rootstock plants, and through topworking, as there is no known vector. Currently, there are no procedures to certify that apple seedlings or budwood produced in Korea are free of ACLSV (Lee et al., 2013). Production and cultivation of virus-free material is fundamentally important to retard the spread of ACLSV and enhance productivity of apple trees in Korea. It is therefore important to breed and select ACLSV resistant plants, and desirable to have well-characterized local isolates with which to challenge-inoculate breeding stocks.

ACLSV is the type species of the genus Trichovirus, and has a single-stranded positive sense RNA genome of 7,4747,561 nucleotides excluding the poly(A) tail (German et al., 1990; Guo et al., 2016; Sato et al., 1993). The genomic RNA consists of 3 open reading frames (ORFs); ORF1 encodes the replication-associated protein, ORF2 the $50 \mathrm{kDa}$ movement protein, and ORF3 the coat protein. ACLSV has been detected in Chungcheong and Gyeongsang Provinces (Han et al., 2015) by RT-PCR using primers ACLSV_ F and ACLSV_R (Menzel et al., 2002), but there is still little information about this emerging virus in Korea. We therefore constructed an infectious clone of ACLSV-GW, originating from Gunwi, Gyeongsangbuk-do.

We first designed RACE primers to sequence the $5^{\prime}$ non-coding region (NCR) of ACLSV-GW. Total RNA was extracted from ACLSV PCR-positive tissue using the RNeasy Mini kit (Qiagen Inc., Hilden, Germany) and amplification performed with 5' RACE system for Rapid Amplification of cDNA Ends, v. 2.0 (Thermo Fisher Scientific Inc., Waltham, MA, USA) by the respective manufacturers' protocols, using Gene specific primers (GSP) for $5^{\prime}$ RACE PCR (Table 1). PCR conditions were: 5 min at $94^{\circ} \mathrm{C}$, followed by 37 cycles of $30 \mathrm{~s}, 94^{\circ} \mathrm{C} ; 30 \mathrm{~s}, 53^{\circ} \mathrm{C}$; and $30 \mathrm{~s}, 72^{\circ} \mathrm{C}$; and $7 \mathrm{~min}$ final extension, using Blend $\mathrm{Taq}^{\circledR}$ polymerase (TOYOBO Co., Osaka, Japan). Amplified products were purified with MG PCR Product Purification SV (MGMED Inc., Seoul, South Korea), cloned into Tblunt vector Solgent, Daejeon, South Korea, and sequenced (Macrogen Inc, Seoul, South Korea). Based on RACE results of $5^{\prime}$ NCR, and 3' conserved NCR sequences of other ACLSV isolates, we designed primers SalI_T7_CL_F and T30_XbaI_CL_R (Table 1) to amplify the full length product. Total RNA $(1 \mu \mathrm{g})$ from ACLSV infected tissue and $1 \mu \mathrm{g}$ of Oligo dT18 $(10 \mathrm{pmol} / \mu \mathrm{l})$ primer were mixed with RNase-free water to $12 \mu \mathrm{l}$, and incubated at $65^{\circ} \mathrm{C}$ for $5 \mathrm{~min}$. Then $2 \mu \mathrm{l}$ of dNTPs ( $10 \mathrm{mM}$ each), $1 \mu \mathrm{l}$ RNase inhibitor, $4 \mu \mathrm{l} 5 \mathrm{x}$ RT buffer, and ReverTra Ace- $\alpha-{ }^{\circledR}$ (TOYOBO Co., Ltd.) were added to the RNA-primer mixture for cDNA synthesis, incubated at $50^{\circ} \mathrm{C}$ for $20 \mathrm{~min}$, and the reaction terminated at $99^{\circ} \mathrm{C}$ for $5 \mathrm{~min}$. The subsequent PCR mixture consisted of $1 \mu \mathrm{l}$ cDNA, $25 \mu \mathrm{l}$ 2X buffer, $1 \mu \mathrm{l}$ SalI_T7 CL_F (10 pmol) and $1 \mu \mathrm{l}$ T30_XbaI_CL_R (10pmol) (Table 1), $10 \mu \mathrm{l} 2 \mathrm{mM}$ dNTPs, $1 \mu \mathrm{l}$ KOD FX neo (TOYOBO Co., Ltd.), and $11 \mu \mathrm{l}$ distilled water. PCR conditions were: 2 min at $94^{\circ} \mathrm{C}$, and 33 cycles of $10 \mathrm{~s}, 98^{\circ} \mathrm{C} ; 30 \mathrm{~s}, 63^{\circ} \mathrm{C}$; and 4 min, $68^{\circ} \mathrm{C}$. PCR products were purified as above, digested

Table 1. Primers used in this study

\begin{tabular}{|c|c|c|c|}
\hline Name & Sequence $\left(5^{\prime} \rightarrow 3^{\prime}\right)$ & Feature & Expected size \\
\hline SalI_T7_CL_F & $\begin{array}{l}\text { AAA } \boldsymbol{G} \boldsymbol{T} \boldsymbol{C} \boldsymbol{G} \boldsymbol{A} \boldsymbol{C} \text { TAATACGACTCACTATAGGATACTGATA- } \\
\text { CAGTGTACACTCAC }\end{array}$ & $\begin{array}{l}\text { SalI } \\
\text { T7 Promoter } \\
\text { (For amplify the full } \\
\text { length ACLSV) }\end{array}$ & \multirow[t]{2}{*}{ 7,590 bp } \\
\hline T30_XbaI_CL_R & $\begin{array}{l}\text { GAGTCTAGATTTTTTTTTTTTTTTTTTTTTTTTTTTTTTG- } \\
\text { TAGTAAAATATTTAAAAGTCTACAGGC }\end{array}$ & $X b a I$ & \\
\hline GSP1 & TCAATTGAGATGTCAGCATC & $\begin{array}{l}\text { For 5' Race PCR } \\
\text { (cDNA synthesis) }\end{array}$ & - \\
\hline GSP2 & GGTTCTCCAGAGTTTTGCAAC & For 5' Race PCR & $\begin{array}{c}392 \text { bp } \\
\text { With Abridged } \\
\text { Anchor Primer }\end{array}$ \\
\hline $\begin{array}{l}\text { CL_qPCR_F } \\
\text { CL_qPCR_R }\end{array}$ & $\begin{array}{l}\text { ATGTGGTCGTGGAGGTCAA } \\
\text { CGGGTCCGAAGATGTAGTC }\end{array}$ & For Real-time qRT-PCR & $110 \mathrm{bp}$ \\
\hline $\begin{array}{l}\text { ACLSV_F } \\
\text { ACLSV_R }\end{array}$ & $\begin{array}{l}\text { TTCATGGAAAGACAGGGGCAA } \\
\text { AAGTCTACAGGCTATTTATTATAAGTCTAA }\end{array}$ & $\begin{array}{l}\text { For RT-PCR } \\
\text { (Menzel et al., 2002) }\end{array}$ & $677 \mathrm{bp}$ \\
\hline
\end{tabular}


Apple chlorotic leaf spot virus genome full-length PCR

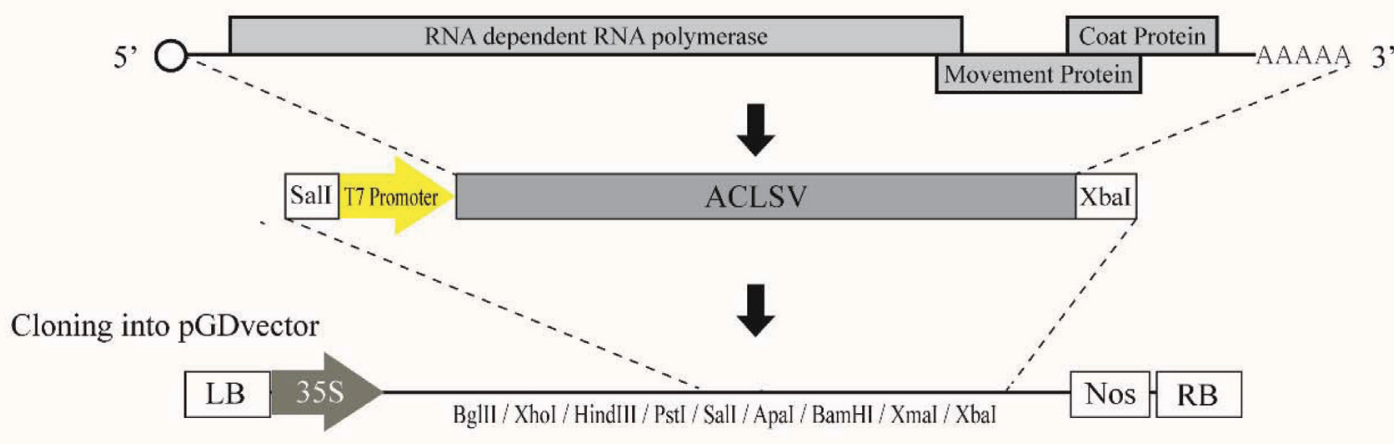

Entire construction of GW

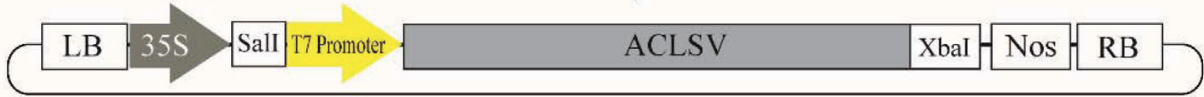

Fig. 1. Diagram of construction of infectious clone of ACLSV-GW. The entire genome of Apple chlorotic leaf spot virus (ACLSV) was amplified. The amplified ACLSV sequence has an added Sall restriction enzyme site and T7 promoter sequence at its 5' terminus and $X b a \mathrm{I}$ restriction enzyme site at its 3' terminus. This product was cloned with binary vector pGD.

with $S a l I$ and $X b a I$, cloned into binary vector pGD (Goodin et al., 2002; Fig. 1), and the cloned sequence of ACLSVGW determined (Macrogen Inc.; GenBank accession number KX506849). A phylogenetic tree was constructed by the maximum-likelihood method with 1,000 bootstrap replicates, using MEGA version 6 (Tamura et al., 2013), to compare ACLSV-GW to 14 full-length ACLSV sequences available from NCBI GenBank. The full sequence of Cherry mottle leaf virus (CMLV; Trichovirus) was used as outgroup for the phylogenetic tree. Sequence alignment was performed using Clustal Omega and DNAMAN (Lynnon LLC, San Ramon, CA, USA).

Sequence analysis indicated that ACLSV-GW is most closely related to Japanese isolate A4 (84\% identity); four further isolates from Japan, India and China having $>80 \%$ nucleotide identities (Fig. 2) also fell within a clade of isolates from apple. Two other clades included isolates from stone (plum and peach) or pome fruit (apple,

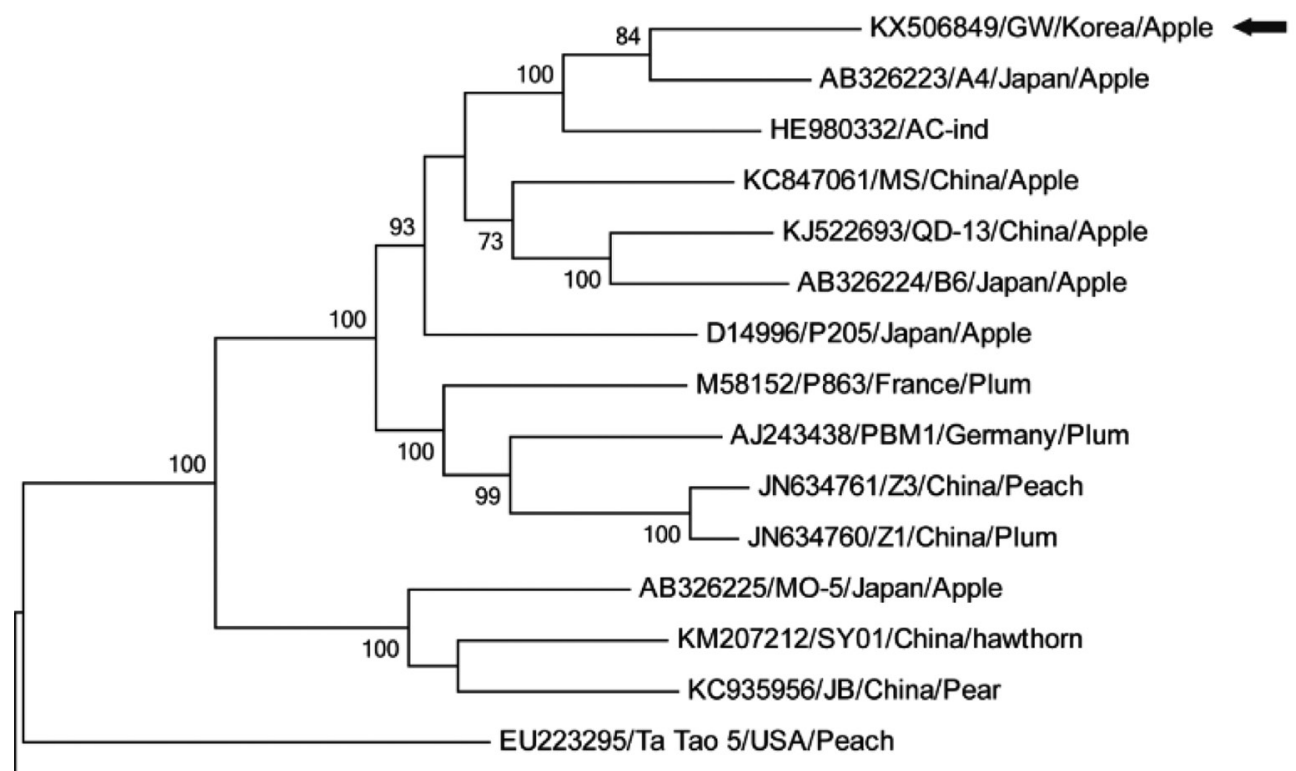

NC 002500/Cherry mottle leaf virus

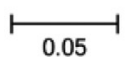

Fig. 2. Phylogenetic tree based on Apple chlorotic leaf spot virus full-length genome sequences. The tree was constructed with MEGA 6.0 using the maximum-likelihood method with 1,000 bootstrap replicates; 14 full-length genome sequences of additional strains of ACLSV were obtained from National Center for Biotechnology Information (GenBank). The labels indicate Accession number/ name of strain/country/host. The numbers at the nodes are bootstrap values above $50 \%$. The scale bar indicates the number of nucleotide substitutions. The black arrow indicates an ACLSV-GW sequence. 
pear, and hawthorn), with a monophyletic clade of a peach isolate from the USA (Fig. 2). There is considerable diversity between isolates of ACLSV from different regions and hosts (e. g., Al Rwahnih et al., 2004; Katsiani et al., 2014), ranging from $67.2-90.2 \%$ full genome nucleotide identity (Guo et al., 2016; Niu et al., 2012). Based on the observed sequence identities and trade practices, we suggest that ACLSV-GW may be derived from apple graft-propagated material originally cultured in Japan.

An infectious clone of Japanese ACLSV isolate P-205 driven by the $35 \mathrm{~S}$ promoter was infectious to $C$. quinoa by either biolistic or mechanical inoculation (Satoh et al., 1999); additional clones of P-205 driven separately by either the $\mathrm{T} 7$ or $35 \mathrm{~S}$ promoters were infectious to C. quinoa (T7 transcripts; 35S, biolistic and agroinoculation), N. occidentalis (35S, biolistic and agroinoculation), and peach seedlings (35S, agroinfiltration) (Youssef et al., 2011). In our experiments we cloned a full-length Korean ACLSV isolate in a binary vector containing both the $35 \mathrm{~S}$ and $\mathrm{T} 7$ promoters for versatile use by in vitro transcription or agroinfiltration from a single construct. For in vitro transcription plasmid DNA was linearized by digestion with $X b a \mathrm{I}$, extracted twice with phenol/chloroform, then purified with MG PCR Product Purification SV. The transcription mixture contained $4 \mu \mathrm{g}$ linearized plasmid DNA, $10 \mu \mathrm{l}$ Transcription Optimized 5X Buffer, $5 \mu 100$ mM DTT, 50 units Promega, Madison, WI, USA, $5 \mu$ l rNTP capping mix, 5 $\mu 15$ mM Ribo m7G Cap Analog, 40 units T7 RNA polymerase, and RNase free water to $50 \mu$ l. The mixture was incubated at $37^{\circ} \mathrm{C}$ for $1 \mathrm{~h}$, and then an additional 20 units of T7 RNA polymerase added and incubated for 1 $\mathrm{h}$ longer. The integrity of transcribed RNA was evaluated by electrophoresis of an aliquot through a $1 \%$ agarose gel. The remainder of the mixture was precipitated with ethanol and eluted with $30 \mu \mathrm{l}$ of GKP buffer pre-warmed to $58^{\circ} \mathrm{C}$. Two leaves per $C$. quinoa plant were rubbed with $5 \mu l$ each of transcribed RNA. After 10 min, inoculated leaves were washed with distilled water. At 20 days post inoculation (dpi), total RNA of newly developed leaves near the top of plants were extracted by TRI Reagent ${ }^{\circledR}$ (Molecular Research Center Inc., Cincinnati, OH, USA) according to the manufacturer's protocol and cDNAs were synthesized as described above. RT-PCR for detection was carried out as reported (Han et al., 2015). Fig. 3 shows leaves of $C$. quinoa inoculated with in vitro transcripts; although no obvious visible symptom were produced, RT-PCR of upper leaves yielded positive results, and bioassay verified that the leaves without symptoms contained infectious virus.

Previously, versatile binary vectors containing both the $35 \mathrm{~S}$ and $\mathrm{T} 7$ promoters were used to construct infectious

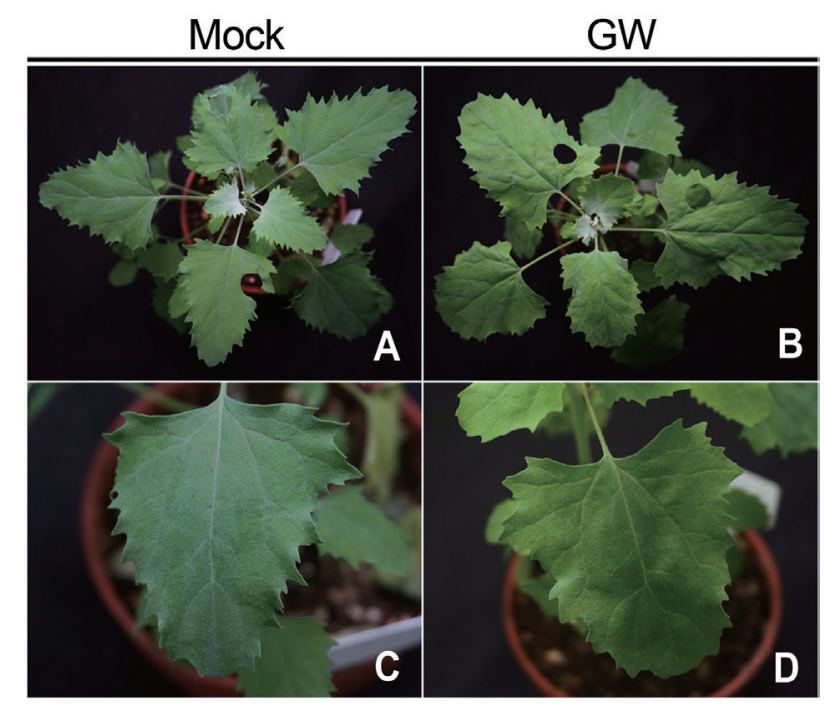

\section{C. quinoa}

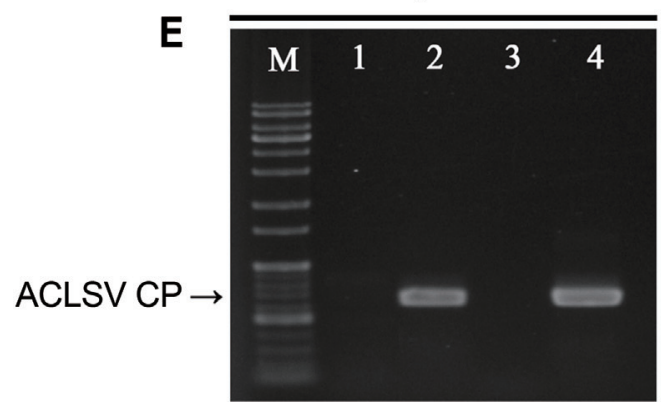

Fig. 3. C. quinoa mock-inoculated with GKP buffer (A, C) and inoculated with RNA transcripts of ACLSV-GW (B, D) 20 days post inoculation. (C, D) Close-up views of upper uninoculated leaf (no symptoms but RT-PCR and bioassay positive for D). (E) RT-PCR of in vitro transcript inoculated C. quinoa. Lane 1) Healthy plant, 2) ACLSV transcript inoculated plant, 3) Mock inoculated plant, and 4) positive control for PCR reaction using ACLSV plasmid DNA.

clones of AltMV, PVX, TuMV, and CGMMV (Lim et al., 2010; Park et al., 2017 and unpublished). However, a dual purpose ACLSV infectious clone has not previously been produced. C. quinoa and N. occidentalis were agroinfiltrated with pGD:ACLSV at inoculum concentrations of 0.6 , 0.8 , and $1.0 \mathrm{OD}_{600}$ mixed with $1 / 10$ volume of pGD:R007 HC-Pro (Han et al., 2016) at $0.6 \mathrm{OD}_{600}$. At $32 \mathrm{dpi}$, young upper leaves were assayed for ACLSV infection by realtime qRT-PCR. Total RNAs of C. quinoa and N. occidentalis were extracted with Molecular Research Center Inc., Cincinnati, OH, USA and then with phenol; cDNA was synthesized from $500 \mathrm{ng}$ total RNA. The qRT-PCR mixture consisted of $1 \mu \mathrm{l}$ of cDNA, $10 \mu \mathrm{l}$ of $\mathrm{iQ}^{\mathrm{TM}} \mathrm{SYBR}^{\circledR}$ Green supermix (2X) (Bio-Rad Laboratories Inc., Hercules, 
Table 2. Detection of ACLSV-GW using quantitative real-time RT-PCR

\begin{tabular}{ccc}
\hline & $\begin{array}{c}\text { N. occidentalis } \\
\text { (Ct value) }\end{array}$ & $\begin{array}{c}\text { C. quinoa } \\
\text { (Ct value) }\end{array}$ \\
\hline 1 & $\mathrm{~N} / \mathrm{D}^{*}$ & $\mathrm{~N} / \mathrm{D}$ \\
2 & $\mathrm{~N} / \mathrm{D}$ & $\mathrm{N} / \mathrm{D}$ \\
3 & $\mathrm{~N} / \mathrm{D}$ & $\mathrm{N} / \mathrm{D}$ \\
4 & $\mathrm{~N} / \mathrm{D}$ & $\mathrm{N} / \mathrm{D}$ \\
5 & $26.76 \pm 0.04$ & $\mathrm{~N} / \mathrm{D}$ \\
6 & $\mathrm{~N} / \mathrm{D}$ & $\mathrm{N} / \mathrm{D}$ \\
7 & $\mathrm{~N} / \mathrm{D}$ & $\mathrm{N} / \mathrm{D}$ \\
8 & $\mathrm{~N} / \mathrm{D}$ & $\mathrm{N} / \mathrm{D}$ \\
9 & $\mathrm{~N} / \mathrm{D}$ & $\mathrm{N} / \mathrm{D}$ \\
10 & $\mathrm{~N} / \mathrm{D}$ & $\mathrm{N} / \mathrm{D}$ \\
11 & $22.18 \pm 0.04$ & $\mathrm{~N} / \mathrm{D}$ \\
12 & $\mathrm{~N} / \mathrm{D}$ & $\mathrm{N} / \mathrm{D}$ \\
Negative control & $\mathrm{N} / \mathrm{D}$ & $\mathrm{N} / \mathrm{D}$ \\
Positive control & $12.44 \pm 0.05$ & $13.20 \pm 0.04$ \\
\hline
\end{tabular}

N/D: Not detected.

Three replicates of each sample (71 ng of each cDNA sample).

CA, USA), $0.5 \mu$ each of CL_qPCR F and CL_qPCR $\mathrm{R}$ (10 pmol) (Table 1), and $8 \mu \mathrm{l}$ distilled water; qRT-PCR conditions were: $3 \mathrm{~min}$ at $95^{\circ} \mathrm{C}, 40$ cycles of $10 \mathrm{~s} 95^{\circ} \mathrm{C}, 10 \mathrm{~s}$ $58^{\circ} \mathrm{C}$, and $20 \mathrm{~s} 72^{\circ} \mathrm{C}$, followed by melting at $0.5^{\circ} \mathrm{C}$ increments from $65^{\circ} \mathrm{C}$ to $95^{\circ} \mathrm{C}$. No infection of $C$. quinoa was obtained by agroinfiltration, but two of twelve $N$. occidentalis plants inoculated with $0.8 \mathrm{OD}_{600} \mathrm{pGD}$ :ACLSV were infected with ACLSV-GW (Table 2). As for C. quinoa, no obvious symptoms were observed (Fig. 4), but qRT-PCR yielded positive results.

These results contrast with those of Youssef et al. (2011), who were able to infect $C$. quinoa, but not $N$. occidentalis, by transcript inoculation in parallel experiments. It may be that host-specific adaptations of the ACLSV genome affect the ability to infect these two hosts (Youssef et al., 2011).

We report here rapid generation of a full-length infectious clone for both in vitro transcription and agroinfiltration inoculation of ACLSV using a single construct. Due to their long cropping cycle, frequent trade of propagation material with neighboring countries, and now also climate change, tree-fruit crops remain susceptible to introduction of new virus isolates. Our method for generation of a full length ACLSV infectious clone suitable for both transcript inoculation and agroinfiltration could be useful for studies in woody crop plants such as apple and pear, and, for ACLSV and other viruses, especially for the validation of rapid selection in breeding programs to select lines with resistance against emerging viruses. Whereas we have not

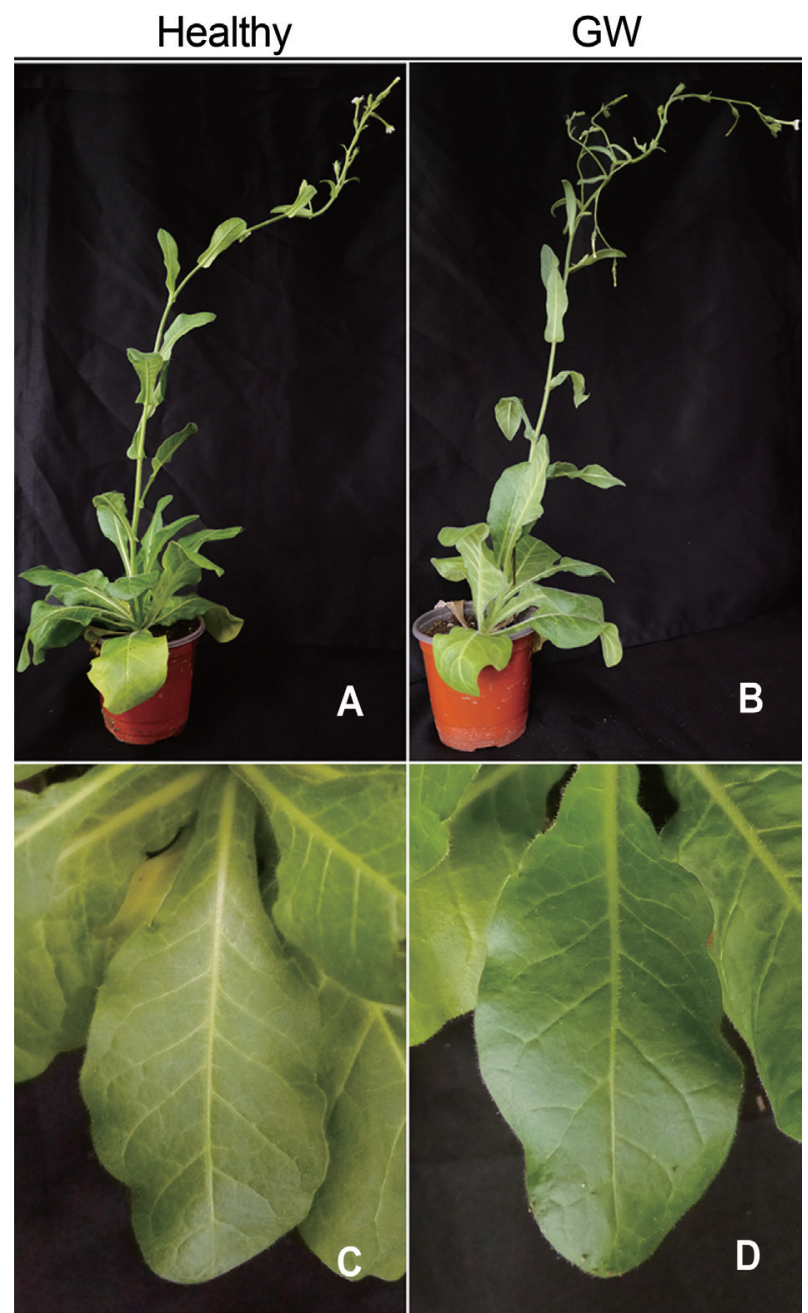

Fig. 4. Healthy Nicotiana occidentalis (A, C) and N. occidentalis infected with ACLSV-GW by agroinfiltration (B, D) 32 days post inoculation (no symptoms but RT-PCR and bioassay positive). Entire views (A, B) and close-up views (C, D) of plants.

yet tested direct inoculation of apple, Youssef et al. (2011) were able to infect peach seedlings by agroinfiltration, suggesting that either direct agroinfiltration or inoculation of apple from $N$. occidentalis tissue in which infection was established by agroinfiltration will be possible.

\section{Acknowledgments}

This research was carried out with the support of "Cooperative Research Program for Agriculture Science \& Technology Development (Project No. PJ01007703)" Rural Development Administration, Republic of Korea.

\section{References}

Al Rwahnih, M., Turturo, C., Minafra, A., Saldarelli, P., Myrta, A., 
Pallás, V. and Savino, V. 2004. Molecular variability of Apple chlorotic leaf spot virus in different hosts and geographical regions. J. Plant Pathol. 86:117-122.

Cembali, T., Folwell, R. J., Wandschneider, P., Eastwell, K. C. and Howell, W. E. 2003. Economic implications of a virus prevention program in deciduous tree fruits in the US. Crop Prot. 22:1149-1156.

Cho, I. S., Igori, D., Lim, S. M., Choi, G. S., Hammond, J., Lim, H. S. and Moon, J. S. 2016. Deep sequencing analysis of apple infecting viruses in Korea. Plant Pathol. J. 32:441-451.

German, S., Candresse, T., Lanneau, M., Huet, J. C., Pernollet, J. C. and Dunez, J. 1990. Nucleotide sequence and genomic organization of Apple chlorotic leaf spot closterovirus. Virology 179:104-112.

Goodin, M. M., Dietzgen, R. G., Schichnes, D., Ruzin, S. and Jackson, A. O. 2002. pGD vectors: versatile tools for the expression of green and red fluorescent protein fusions in agroinfiltrated plant leaves. Plant J. 31:375-383.

Guo, W., Zheng, W., Wang. M., Li, X., Ma, Y. and Dai, H. 2016. Genome sequences of three Apple chlorotic leaf spot virus isolates from hawthorns in China. PLoS One 11:e0161099.

Han, J. Y., Kim, J. K., Cheong, J. S., Seo, E. Y., Park, C. H., Ju, H. K., Cho, I. S., Gotoh, T., Moon, J. S., Hammond, J. and Lim, H. S. 2015. Survey of Apple chlorotic leaf spot virus and Apple stem grooving virus occurrence in Korea and frequency of mixed infections in apple. J. Fac. Agr. Kyushu Univ. 60:323329.

Han, J. Y., Chung, J. S., Kim, J. K, Seo, E. Y., Kilcrease, J. P., Bauchan, G. R., Lim, S. M., Hammond, J. and Lim, H. S. 2016. Comparison of helper component-protease RNA silencing suppression activity, subcellular localization, and aggregation of three Korean isolates of Turnip mosaic virus. Virus Genes 52:592-596.

Katsiani, A. T., Maliogka, V. I., Candresse, T. and Katis, N. I. 2014. Host-range studies, genetic diversity and evolutionary relationships of ACLSV isolates from ornamental, wild and cultivated Rosaceous species. Plant Pathol. 63:63-71.

Lee, G. P., Ryu, K. H., Kim, H. R., Kim, C. S., Lee, D. W., Kim, J. S., Park, M. H., Noh, Y. M., Choi, S. H., Han, D. H. and Lee, C. H. 2002. Cloning and phylogenetic characterization of coat protein genes of two isolates of Apple mosaic virus from 'Fuji' apple. Plant Pathol. J. 18:259-265.

Lee, G. S., Kim, J. H., Kim, H. R., Shin, I. S., Cho, K. H., Kim, S. H., Shin, S. H. and Kim, D. H. 2013. Production system of virus-free apple plants using heat treatment and shoot tip culture. Res. Plant Dis. 19:288-293.

Lim, H. S., Vaira, A. M., Domier, L. L., Lee, S. C., Kim, H. G. and Hammond, J. 2010. Efficiency of VIGS and gene expression in a novel bipartite potexvirus vector delivery system as a function of strength of TGB1 silencing suppression. Virology 402:149-163.

Menzel, W., Jelkman, W. and Maiss, E. 2002. Detection of four apple viruses by multiplex RT-PCR assays with coamplification of plant mRNA as internal control. J. Virol. Methods 99:81-92.

Nemchinov, L., Hadidi, A., Candresse, T., Foster, J. A. and Verdervskaya, T. C. 1995. Sensitive detection of Apple chlorotic leaf spot virus from infected apple or peach tissue using RT-PCR, IC-RT-PCR, or multiplex IC-RT-PCR. Acta Hortic. 386:51-62.

Niu, F., Pan, S., Wu, Z., Jiang, D. and Li, S. 2012. Complete nucleotide sequences of the genomes of two isolates of Apple chlorotic leaf spot virus from peach (Prunus persica) in China. Arch. Virol. 157:783-786.

Park, C. H., Ju, H. K., Han, J. Y., Park, J. S., Kim, I. H., Seo, E. Y., Kim, J. K., Hammond, J. and Lim, H. S. 2017. Complete nucleotide sequences and construction of full-length infectious cDNA clones of cucumber green mottle mosaic virus (CGMMV) in a versatile newly developed binary vector including both $35 \mathrm{~S}$ and T7 promoters. Virus Genes 53:286-299.

Sato, K., Yoshikawa, N. and Takahashi, T. 1993. Complete nucleotide sequence of the genome of an apple isolate of Apple chlorotic leaf spot virus. J. Gen. Virol. 74:1927-1931.

Satoh, H., Yoshikawa, N. and Takahashi, T. 1999. Construction and biolistic inoculation of an infectious cDNA clone of Apple chlorotic leaf spot trichovirus. Ann. Phytopathol. Soc. Jpn. 65:301-304.

Tamura, K., Stecher, G., Peterson, D., Filipski, A. and Kumar, S. 2013. MEGA6: molecular evolutionary genetics analysis version 6.0. Mol. Biol. Evol. 30:2725-2729.

Wu, Y. Q., Zhang, D. M., Chen, S. Y., Wang, X. F. and Wang, W. H. 1998. Comparison of three ELISA methods for the detection of Apple chlorotic leaf spot virus and Apple stem grooving virus. Acta Hortic. 472:55-60.

Youssef, F., Marais, A., Faure, C., Gentit, P. and Candresse, T. 2011. Strategies to facilitate the development of uncloned or cloned infectious full-length viral cDNAs: Apple chlorotic leaf spot virus as a case study. Virol. J. 8:488. 